\title{
Higher Education and European Citizenship as a Matter of Public Concern
}

\author{
GERT BIESTA \\ The Stirling Institute of Education, University of Stirling, United Kingdom \\ MAARTEN SIMONS \\ Centre for Educational Policy and Innovation/Centre for \\ Philosophy of Education, Catholic University of Leuven, Belgium
}

With the growth of the European Union - both in terms of its size and in terms of its influence and importance - questions have emerged about the relationship between the European Union and the inhabitants of its member states. These questions are increasingly being framed in relation to the idea of citizenship. The issue here is not only whether such a thing as European citizenship can exist. The issue is also what we should understand by European citizenship and, in relation to this, how European citizenship can be promoted and advanced. These questions are first of all considered to be important in relation to the democratic legitimacy of the European Union on the assumption that the legitimacy of democratic governance crucially depends on the extent to which it is supported and 'owned' by its citizens. But they are also considered to be important in relation to wider questions about social cohesion and integration and the emergence of something like a sense of a European identity.

Whereas many opportunities for civic participation and identification are located at national and sub-national levels, there is at least one area where over the past decade something with a more European identity has been emerging. This is the field of higher education.[1] While compulsory education and, to a slightly lesser extent, vocational education have largely remained tied to national priorities, agendas and policies, the field of higher education is rapidly evolving into a sector which transcends national borders and agendas. Although the economic imperative is central in the policies that drive these developments, particularly in relation to the ambition of the European Community to become 'the most competitive and dynamic knowledge-based economy in the world with more and better jobs and greater social cohesion' (Lisbon European Council, 2000), policy makers are clearly aware of the wider potential of universities in relation to questions of social cohesion and European citizenship (see, for example, European Commission, 2003, 2006). This is also what has been emphasised by the European universities themselves, who have stressed that their role encompasses more than just the creation of the next generation of workers for the knowledge economy, but includes a responsibility for cultural, social and civic development at national and European level (see, for example, European University Association, 2003).

There are indeed good reasons for focusing on the higher education sector in relation to questions about European citizenship. One reason goes back to the Humboldtian tradition, which has always given the university a special role in the development of the democratic nation-state, a line of thinking which is now extended to the European level. This line of thought traditionally stresses the unique role of 'academic' education, that is, the edifying potential of research-based education in institutions for higher education. A second reason for a focus on higher education has 
to do with the fact that higher education is one of the areas where a form of European integration is actually taking shape in a way that is not exclusively tied to economic issues and interests, which makes universities important players for strengthening the socio-cultural and political dimensions of European citizenship. A third reason for focusing on higher education is that the sector is no longer the prerogative of the elites but that mass higher education is now the reality in most European countries, with many of them reaching levels of participation of well over $50 \%$. Contemporary higher education covers both traditional academic and professional education, and through outreach programmes, lifelong learning and involvement in local and regional communities, its impact stretches even further than to those directly involved as students. Finally, it could be argued that the higher education sector is an exemplary 'case' in relation to many of the issues that are at stake in discussions about European citizenship, such as the tension between national and European interests, the tension between economic and democratic imperatives, the tension between the public and the private sphere, the tension between widening participation and maintenance of standards, the tension between top-down and bottom-up forms of governance, the tension between collaboration and competition, and issues concerning social inclusion and the participation of minorities and migrants, women, and both the young and the elderly.

While there is, therefore, a prima facie case for exploring the role of European higher education in the promotion and development of European citizenship, one of the important issues is how this question should be taken up. From the standpoint of European policy there is a strong tendency to stress the need for the development of curricula, extra-curricular activities and participation structures that offer students opportunities to develop civic competencies (see Biesta, this issue). This is part of a wider demand for the modernisation of European higher education (European Commission, 2006) based on the assumption that existing organisational structures, governance and management systems, curricula and teaching methods, and funding and incentives mechanisms are no longer considered to be adequate to guarantee that European universities can keep up with global competition in education, research and innovation. This demand also extends to the domain of citizenship on the assumption that today's knowledge-intensive economies and societies are also in need of up-to-date policies on equal opportunities, participation and access, and of strategies for knowledge-driven local and regional economic, social and cultural development.

Citizenship has emerged in these discussions in three, partly related, ways. At a general level, democratic citizenship is suggested to be a solution for a particular set of problems: the imbalance in the European project due to its focus on economic issues, the lack of democratic deliberation and social participation in post-welfare regimes and the necessity to develop democratic involvement in governance at the European scale. The question of European citizenship is framed here as a policy problem regarding the lack of democratic involvement and social and political participation. Secondly, and in view of offering a solution to the problem, it is assumed that democratic citizenship can be developed and that universities have to play a role in that respect. In line with this framing, developing democratic citizenship is approached as a learning problem and translated in terms of developing democratic citizenship competencies. Thirdly, universities are approached as sites that can and have to be mobilised and made responsible for offering opportunities for the development of citizenship competencies. At this level, the question of democratic citizenship turns into an educational and organisational reform problem.

The contributions to this special issue do not simply take the way in which the question of European citizenship in relation to European higher education has been framed by policy makers for granted. Rather than trying to answer the question how European universities can contribute to the development of European citizenship, the articles in this special issue aim to disentangle the different framings of this nexus through an exploration of assumptions and choices and a discussion of the consequences of different ways of articulating the alleged problem of European citizenship in relation to the field of higher education. By doing so, the contributions aim to broaden the spectrum of understandings about European citizenship and also to highlight different ways in which universities, as very specific and in a sense 'unique' institutions, can contribute in a way that goes beyond the mere 'production' of 'good citizens'.

In the first article Gert Biesta provides an analysis of the idea of the active citizen - an idea which not only seems to be the prominent configuration of citizenship within European policy but also one that has become the focus of attention in research on the development of European citizenship. He argues that the idea of the active citizen as operationalised in policy and research 
has a tendency to depoliticise the very idea of citizenship by pursing a functionalist notion of citizenship connected to a consensus idea of democracy. Against the background of this analysis he suggests that higher education should resist becoming a socialising agent for the production of the competent active citizen. Instead, Biesta calls on higher education institutions to support modes of political action and civic learning that embody a commitment to a more critical and more political form of European citizenship.

Elaborating on this critical diagnosis, the following contributions each explore further tensions in current framings of the question of higher education's contribution to active citizenship and civic competence. In their article, Grahame Lock \& Hermínio Martins look critically at the idea of citizenship itself. Discussing Aristotle's and Hegel's conception of citizenship, they reveal the contrast between the state and civil society and its consequences for the concept of citizenship in relation to Bildung ('general edification'). Based on their critical diagnosis of the current marketised university as a 'psychotic organisation', they seek to problematise what they refer to as the compensating ideology of 'citizenism' and to open up a perspective to look at new forms of citizenship around real social struggles.

Pavel Zgaga takes the current framing of the purposes of higher education institutions in view of the European knowledge economy and society as his focus. Introducing four 'archetypal models' of understanding the purposes of higher education (Napoleonic, Humboldtian, Newmanian and Deweyan), he discusses the current instrumentalisation of European higher education in confrontation with processes of internationalisation and globalisation. Based on this critical understanding he stresses the importance of addressing the 'full range of purposes' of higher education in relation to its contribution to the promotion of citizenship.

A further step in disentangling the current framing is taken by Vassiliki Papatsiba in her discussion of student mobility programmes, which are traditionally regarded as an important strategy to promote European citizenship. She clarifies how these programmes function as technologies of government that seek to empower entrepreneurial actors in surpassing the limits of national boundaries and parochial institutional rationales, looking for learning opportunities beyond national territoriality and finding ways to accumulate personal experiences and virtues. Noticing the individualistic, entrepreneurial framing of student mobility, she discusses to what extent the public dimension of citizenship is supported and promoted.

Maarten Simons \& Jan Masschelein focus their analysis on the specific framing of the public role of the university against the background of entrepreneurial tendencies within the ways in which universities understand themselves. They characterise the focus on offering opportunities for developing citizenship competencies as a strategy of immunisation that actually prevents universities from becoming concerned with public issues and from gathering a public around these issues. Thus they make a case for connecting the question of European citizenship to the wider question of the public role of European higher education.

The contribution of Marek Kwiek provides a further exploration of the current framing of the question of citizenship within higher education. He takes his point of departure as the current policy discourse on promoting the attractiveness of European universities. Revealing the complexities in the current articulation of attractiveness, and particularly the challenges posed to academics, his analysis results in the identification of a number of specific areas that would have to be addressed at the level of policy in order to actually promote the attractiveness of higher education. The question of the tension between national/traditional and European interests is considered to be particularly important in relation to this.

Taken together, the contributions in this order suggest a shift from the question of how universities can produce a particular kind of active citizenship in order to meet the demands of the European Union and its member states towards the question about the public role of universities and, more specifically, the question as to what European universities have to offer to Europe and its member states based on this specific role. Rather than put universities in a responsive position, the contributions in this issue thus suggest a more proactive role for higher education. In the final contribution to this issue Jan Masschelein \& Maarten Simons explore this alternative framing by suggesting that universities can create opportunities where things can be made public and can become a matter of public concern and where the public can constitute themselves around such issues. The role of the professor as someone who makes something - and more specifically some 
thing - public is seen as central in the way in which the university can contribute to citizenship (and more specifically a form of 'world citizenship') in a different way.

The argument developed through the contributions in this special issue not only indicates a different set of priorities for European higher education but also suggests a different research agenda. In the concluding contribution to this issue the authors of the articles present an outline of such a research agenda, one that focuses on the public role of the university and questions the potentially public character of the different acts and activities that occur within the field of higher education. Implied in this research agenda is the idea that the future of European higher education should itself be seen as a matter of public concern, which means that the further development of such an agenda is too important to be left in the hands of experts and policy makers. This is why the research agenda is explicitly presented as a public research agenda and as a call to make the future of European higher education indeed into a public concern.

\section{Note}

[1] In this issue we will mostly use the terms 'higher education' and 'university' interchangeably, unless there is a particular reason to make a distinction between the two. European policy appears to use the term 'university' as the overarching one, defining it as referring to 'all institutions for higher education, irrespective of their name and status in the Member States' (European Commission, 2006, p. 2).

\section{References}

European Commission (2003) The Role of the Universities in the Europe of Knowledge. COM (2003) 58, Brussels.

European Commission (2006) Delivering on the Modernization Agenda for Universities: education, research and innovation. COM (2006) 208, Brussels.

European University Association (2003) Response to the Communication of the Commission 'The Role of the Universities in the Europe of Knowledge'. Brussels: European University Association.

Lisbon European Council (2000) Presidency Conclusions (Lisbon, 23-24 March 2000).

http://www.europarl.europa.eu/summits/lis1_en.htm

Correspondence: Maarten Simons, Centre for Educational Policy and Innovation, Catholic University of Leuven, B-3000 Leuven, Belgium (maarten.simons@ped.kuleuven.be); Gert Biesta, The Stirling Institute of Education, University of Stirling, Stirling FK9 4LA, United Kingdom (gert.biesta@stir.ac.uk). 